\title{
NIKAH SIRI DALAM PERSPEKTIF HUKUM PERKAWINAN NASIONAL
}

\author{
Oky Deviany Burhamzah \\ Fakultas Hukum, Universitas Hasanuddin \\ E-mail: okydeviany@gmail.com
}

\begin{abstract}
Marriage is one of the importants event in human lifes, particularly for moslem family. Bacause of its important, then marriage regulated not only on state laws, but in Al-quran as well. In Marriage Law in Section 1 of Article 1, mentioned that marriage is legal if conducted according to their religion and beliefs. Meanwhile in Section 2 of Article 2, mentioned that each marriage noted according to the applicable law. Based on that articles above, then marriage registration is not legality condition of marriage. Nikah Siri that conducted without registered, but according to the principles and condition of islamic marriage law. This is give rise to pro and contra in the society related to that legality of marriage.
\end{abstract}

\section{Keywords: Nikah Siri, Islamic Law, Marriage}

\begin{abstract}
ABSTRAK
Perkawinan merupakan salah satu peristiwa yang cukup penting dalam kehidupan manusia, khususnya bagi pemeluk agama Islam. Karena pentingnya, maka hal tersebut diatur tidak hanya dalam aturan hukum negara tapi juga diatur dalam kitab suci Al-Quran. Dalam Pasal 2 ayat 1 UU Perkawinan disebutkan bahwa perkawinan adalah sah apabila dilakukan menurut hukum agama dan kepercayaannya masing-masing. Sementara Pasal 2 ayat 2 menyebutkan bahwa tiap-tiap perkawinan dicatat menurut peraturan perundang-undangan yang berlaku. Berdasarkan pasal-pasal tersebut di atas, maka pencatatan perkawinan bukanlah merupakan syarat sahnya suatu perkawinan. Sehubungan dengan hal tersebut, Nikah Siri yang dilakukan tanpa adanya pencatatan, namun pelaksanaannya dilakukan menurut rukun perkawinan Islam, menimbulkan pro dan kontra di kalangan masyarakat, berkaitan legalitas dari perkawinan tersebut.
\end{abstract}

\section{Kata kunci: Nikah Siri, Hukum Islam, Perkawinan}

\section{Pendahuluan}

Rencana pemerintah menyusun

Rancangan Undang-Undang (RUU) Hukum

Materil Peradilan Agama Bidang Perkawinan

yang lebih dikenal dengan nama "RUU

Nikah Siri" menuai pro-kontra di tengah

masyarakat. Pasalnya, RUU tersebut memuat

ketentuan pidana bagi pelaku nikah siri, bahkan nikah siri yang tidak didaftar hingga batas waktu tertentu terancam batal.

Ketentuan semacam ini kontan saja menimbulkan kontroversi.

Bagi mereka yang pro dan mendukung lahirnya RUU ini menilai bahwa sudah saatnya ada ketentuan hukum yang mengatur tentang nikah siri. Tujuannya agar nikah siri tidak digunakan sebagai alat atau justifikasi untuk melakukan pernikahan secara tidak 
bertanggung jawab. Lebih lanjut menurut pandangan warga yang pro pada RUU Nikah Siri ini bahwa lembaga nikah siri sudah terdistori menjadi alat impunitas untuk melangsungkan pernikahan di bawah tangan. Pernikahan Siri atau nikah di bawah tangan sangat rentan disalahgunakan. Banyak pelaku nikah siri berakhir pada perceraian akibatnya anak yang dihasilkan dari hubungan nikah siri menanggung akibatnya dan menjadi korban nikah siri orang tua mereka. Anakanak nikah siri banyak yang tidak mengetahui ayah mereka, bahkan tidak jarang menjadi obyek kekerasan dalam rumah tangga. Belum lag soal hak mendapatkan nafkah atau hak alimentasi bagi anak-anak hasil nikah siri tidak jelas siapa yang harus menanggung, demikian pula soal hak mewaris dari anak-anak hasil hubungan nikah siri juga tidak jelas.

Berdasarkan data Kementerian Agama RI, jumlah perceraian saat ini menunjukkan trend peningkatan dalam kurun waktu lima tahun terakhir (2010-2015). Muharram Marzuki (Kepala Puslitbang Kehidupan Keagamaan Kemenag) mengatakan dari 2 juta pasangan menikah, sebanyak 15-20\% bercerai. Sementara jumlah kasus perceraian yang diputus Pengadilan Tinggi Agama seluruh Indonesia pada tahun 2014 mencapai 382.231, naik sekitar 131.023 kasus dibanding tahun 2010 sebanyak 251.208 kasus.
Tingginya tingkat perceraian dalam lima tahun terakhir mengindikasikan bahwa perlu rambu-rambu yang mengatur tentang nikah siri ini. Meskipun belum ada data yang jelas berapa kontribusi perceraian dari nikah siri, namun dapat diperkirakan cukup besar mengingat status hukum nikah siri yang dilakukan di bawah tangan sangat berpotensi untuk diselewengkan sehingga perceraian dari nikah siri sangat mudah dilakukan dan tidak mendapat perlindungan hukum yang cukup.

Sebaliknya, bagi mereka yang kontra atau menentang RUU Nikah Siri berpandangan bahwa nikah siri bagaimanapun juga sudah sah (legitimate) dari sudut pandang agama, khususnya agama Islam. Bagi kalangan ini berpendirian bahwa pernikahan adalah ibadah dan merupakan hak asasi bagi setiap orang untuk melangsungkan pernikahan sepanjang sah menurut hukum agamanya masing-masing. Oleh karena itu, ketentuan ancaman pidana bagi pelaku nikah siri adalah bentuk kriminalisasi ibadah dan tentu saja bertentangan dengan hak asasi manusia yang dijamin dalam konstitusi.

Di saat muncul perdebatan mengenai RUU Pengadilan Agama serta ancaman pidana bagi pelaku nikah siri, di Kabupaten Cirebon, Jawa Barat, ada 1.200 pasang warga desa melakukan kehidupan dengan nikah siri. Model nikah siri di desa tersebut telah berlangsung turun temurun, di Desa Sinarancang, Kecamatan Mundu, Kabupaten 
Cirebon terdapat 2.000 pasang suami-isteri. Dari jumlah tersebut, 1.200 pasang atau sekitar $60 \%$ memilih nikah siri. Menurut Kepala Desa Sinarancang, pilihan warganya itu dikarenakan nikah siri lebih mudah, murah, dan sah menurut agama Islam.

Meskipun RUU Nikah Siri masih berupa draft awal akan tetapi terlanjur menimbulkan polemik di tengah masyarakat. Menurut Menteri Agama Suryadharma Ali, RUU itu masih jauh panggang dari api sebelum diterapkan di masyarakat. Artinya, masih terdapat banyak kemungkinan sebelum dibahas di DPR dan diaplikasikan secara nyata. Menurut beliau, tidak ada harga mati dalam RUU tersebut, termasuk tentang sanksi pidana.

\section{Analisis dan Diskusi}

Perkawinan dalam istilah agama disebut "nikah", ialah melakukan suatu aqad atau perjanjian untuk mengikatkan diri antara seorang laki-laki dan wanita untuk menghalalkan hubungan kelamin antara belah pihak, dengan dasar sukarela dan keridhoan kedua belah pihak untuk mewujudkan suatu kebahagiaan hidup berkeluarga yang diliput rasa kasih sayang dan ketenteraman dengan cara-cara yang diridhoi oleh Allah (Ahmad Azhar, 1977:10).

Mengenai pengertian perkawinan ini terdapat beberapa perbedaan pendapat antara satu sama lain. Namun, perbedaan pendapat ini sebetulnya bukan untuk memperlihatkan pertentangan yang sungguh-sungguh antara pendapat yang satu dengan yang lain, tapi dari semua rumusan yang dikemukakan, ada satu unsur yang merupakan kesamaan dari seluruh pendapat, yaitu bahwa nikah itu merupakan suatu perjanjian perikatan antara seorang laki-laki dan seorang wanita. Perjanjian di sini bukan sembarang perjanjian seperti perjanjian jual beli atau sewa menyewa, tetapi perjanjian suci untuk membentuk keluarga antara seorang laki-laki dan seorang wanita (Soemiyati,SH, 1986:9). Sebagaimana yang terdapat dalam kitab suci Al-qur'an Surah An-Nisa ayat 21: "perkawinan itu adalah suatu perjanjian yang suci, kuat dan kokoh (mithsaaghaan ghaliizhan).

Undang-Undang Perkawinan No.1 Tahun 1974, dalam Pasal 1 merumuskan pengertian perkawinan sebagai berikut:

" Perkawinan ialah ikatan lahir bathin antara seorang pria dan seorang wanita sebagai suami-isteri dengan tujuan membentuk keluarga (rumah tangga) yang bahagia dan kekal berdasar Ketuhanan Yang Maha Esa”.

Dari rumusan pasal tersebut di atas, terkandung "arti" dan "tujuan" perkawinan. Arti perkawinan, adalah "ikatan lahir bathin antara seorang pria dan seorang wanita sebagai suami isteri”, sedangkan tujuan perkawinan adalah "membentuk keluarga/ rumah tangga yang bahagia dan kekal berdasarkan Ketuhanan Yang Maha Esa”.

Dengan "ikatan lahir bathin" dimaksudkan bahwa perkawinan itu tidak 
hanya cukup dengan adanya "ikatan lahir" atau "ikatan bathin" saja, tetapi harus keduaduanya. Suatu "ikatan lahir" adalah ikatan yang dapat dilihat, mengungkapkan adanya suatu hubungan hukum antara seorang pria dan wanita untuk hidup bersama, sebagai suami isteri, dengan kata lain dapat disebut "hubungan formil". Sebaliknya, suatu "ikatan bathin" adalah merupakan hubungan yang tidak formil, suatu ikatan yang tidak dapat dilihat. Walau tidak dapat dilihat atau tidak nyata, tapi ikatan itu harus ada. Karena tanpa adanya ikatan bathin, ikatan lahir itu menjadi rapuh. (K.Wantjik Saleh, 1976:15).

Dalam Hukum Islam, perkawinan adalah termasuk dalam lapangan "mu'amalat", yaitu yang mengatur hubungan antar manusia dalam kehidupannya di dunia ini. Asaf A.A. Fyse (dalam Nadimah Tanjung, hal.28) menerangkan bahwa perkawinan itu menurut pandangan islam mengandung 3 (tiga) aspek, yaitu: aspek hukum, aspek sosial, dan aspek agama.

Ditinjau dari aspek hukum, perkawinan merupakan suatu perjanjian. Firman Allah dalam Surah An-Nisa:21:

"Bagaimana kamu akan mengambilnya kembali, padahal sebagian kamu telah bercampur dengan yang lain sebagai suami isteri, dan mereka (isteriisterimu) telah mengambil dari kamu janji yang kuat”.

Ditinjau dari aspek sosial, perkawinan mempunyai arti penting, yaitu: Pertama, pada umumnya berpendapat bahwa orang yang melakukan perkawinan atau pernah melakukan perkawinan mempunyai kedudukan yang lebih dihargai daripada mereka yang belum kawin. Khusus bagi kaum wanita, dengan perkawinan akan memberikan kedudukan sosial yang tinggi, karena ia sebagai isteri dan wanita mendapat hak-hak tertentu dan dapat melakukan tindakan-tindakan hukum dalam berbagaibagai lapangan mu'amalat, yang tadinya ketika masih gadis tindakan-tindakannya masih terbatas, harus dengan persetujuan dan pengawasan orang tuanya; Kedua, sebelum adanya peraturan tentang perkawinan, wanita dulu bisa dimadu tanpa batas dan tanpa bisa berbuat apa-apa, tetapi menurut ajaran islam dalam perkawinan mengenai kawin poligami ini hanya dibatasi paling banyak empat orang, itupun dengan syarat-syarat tertentu pula.

Ditinjau dar aspek agama, Islam memandang dan menjadikan perkawinan ini sebagai basis suatu masyarakat yang baik dan teratur, sebab perkawinan tidak hanya dipertalikan oleh ikatan lahir saja, tetapi diikat juga dengan ikatan bathin dan jiwa. Menurut ajaran Islam perkawinan itu tidaklah hanya sebagai suatu persetujuan biasa melainkan merupakan suatu persetujuan suci, dimana kedua belah pihak dihubungkan menjadi pasangan suami isteri atau saling meminta menjadi pasangan hidupnya dengan mempergunakan nama Allah. 
Dalam UU No.1 Tahun 1974 Tentang Perkawinan, disebutkan arti dan tujuan perkawinan, yakni: "Perkawinan adalan ikatan lahir dan bathin antara seorang pria dengan seorang wanita sebagai suami isteri dengan tujuan membentuk keluarga (rumah tangga) yang bahagia dan kekal berdasarkan ketuhanan Yang Maha Esa". Tujuan dan Manfaat Perkawinan Menurut Imam Gazali dalam Abdul Rohman Ghozali (2003:22):

a. Memperoleh keturunan yang sah yg akan melangsungkan keturunan serta

b. memperkembangkan suku-suku bangsa manusia;

c. Memenuhi tuntutan naluriah hidup kemanusiaan;

d. Memelihara manusia dari kejahatan dan kerusakan;

e. Membentuk dan mengatur rumah tangga yang menjadi basis pertama dari masyarakat yang besar di atas dasar kecintaan dan kasih sayang;

f. Menumbuhkan

kesungguhan berusaha mencari rezeki penghidupan yang halal, dan memperbesar rasa tanggung jawab

Sebagai salah satu perbuatan hukum, perkawinan mempunyai akibat hukum. Adanya akibat hukum ini penting sekali hubungannya dengan sahnya perbuatan hukum itu. Suatu perkawinan yang menurut hukum dianggap tidak sah umpamanya, maka aak yang lahir dari perkawinan itu akan merupakan anak yang tidak sah.
Undang-undang No.1 Tahun 1974 tentang Perkawinan menyatakan bahwa perkawinan adalah sah, apabila dilakukan menurut hukum masing-masing agamanya dan kepercayaannya itu (Pasal 2 ayat 1). Dengan penjelasan bahwa tidak ada perkawinan di luar hukum masing-masing agamanya dan kepercayaannya itu, sesuai dengan Undag-undang Dasar 1945.

Dengan demikian, perkawinan mutlak harus dilakukan menurut hukum masingmasing agamanya dan kepercayaannya itu, kalau tidak maka perkawinan itu tidak sah. Yang dimaksud dengan rukun dari perkawinan ialah hakekat dari perkawinan itu sendiri, jadi tanpa adanya salah satu rukun, perkawinan tidak mungkin dilaksanakan, sedangkan yang dimaksud dengan syarat ialah sesuatu yang harus ada dalam perkawinan tapi bukan merupakan hakekat dari perkawinan.. begitupula dengan rukun, apabila salah satu syarat dari perkawinan itu tidak terpenuhi maka perkawinan itu tidak sah.

Abdurrahman Al-Jaziri (Mohammad R.Hasan:2016) menyebut yang termasuk rukun adalah al-ijab dan al-qabul dimana tidak ada nikah tanpa keduanya. Begitu pula dengan Sayyid Sabiq menyimpulkan bahwa menurut fuqaha, rukun nikah terdiri dari al-ijab dan al-qabul, sedangkan yang lain termasuk ke dalam syarat. 
Dengan demikian yang menjadi rukun dan syarat perkawinan menurut Hukum Islam adalah sebagai berikut (Mohd.Idris Ramulyo, 1996:51-53):

1. Adanya calon mempelai (laki-laki dan perempuan);

2. Harus ada 2 orang saksi yg beragama islam;

3. Harus ada wali dari calon pengantin perempuan;

4. Kewajiban membayar mahar bagi pihak pengantin laki-laki;

5. Harus ada pengucapan sighat "ijab dan kabul"

\section{Ad.1. Adanya calon mempelai.}

Pihak-pihak yang hendak

melaksanakan perkawinan, yaitu mempelai pria dan wanita harus memenuhi syaratsyarat tertentu supaya perkawinan yang dilaksanakan menjadi sah hukumnya. Adapun syarat-syarat yang harus dipenuhi adalah sebagai berikut:

- Telah baliq dan mempunyai kecakapan yang sempurna. Jadi kedewasaan di sini selain ditentukan oleh umur masing-masing pihak juga kematangan jiwanya;

- Berakal sehat;

- Tidak karena paksaan, artinya harus berdasarkan kesukarelaan kedua belah pihak;

- Wanita yang hendak dikawini oleh seorang pria bukan termasuk salah satu macam wanita yang haram untuk dikawini. Di dalam Al-qur'an disebutkan macam-macam wanita yg haram dinikahi, yakni: a) karena hubungan darah, karena hubungan susuan, karena hubungan semenda, dan karena sumpah li’an.

\section{Ad.2. Adanya saksi.}

Para ahli Fiqh sepakat bahwa pelaksanaan aqad nikah harus dihadiri oleh saksi-saksi. Karena kehadiran saksi-saksi merupakan rukun atau hakikat dari perkawinan itu sendiri.

Imam Syafi'I berpendapat bahwa perkawinan itu harus ada saksi, beliau mendasarkan diri pada hadist Nabi. Bersabda Rasulullah SAW: "tidak sah nikah kecuali dengan wali dan dua orang saksi yang adil" (H.R.Ahmad bin Hambal)

Imam Abu Hanifa berpendapat bahwa saksi dalam akad nikah adalah merupakan rukun dari akad nikah. Beliau mengqiaskan persaksian dalam akad nikah dalam akad mu'amalah. Kesaksian merupakan rukun dari aqad mu'amalat. Menurut beliau, aqad nikah lebih utama dari akad mu'amalat. Oleh karena itu adanya saksi dalam akad nikah tentu lebih utama dan diperlukan dari pada adanya saksi-saksi dalam akad mu'amalat. Beliau melakukan qias dalam hal ini, karena tidak ada nash yang dapat disajikan sebagai dasar hukum bagi persaksian itu (Saidus Sahar, 1976:47). 


\section{Ad.3. Adanya Wali}

Perwalian dalam istilah Fiqh disebut wilayah yang berarti penguasaan dan perlindungan. Jadi arti dari perwalian menurut Fiqh ialah penguasaan penuh yang didiberikan oleh agama kepada seseorang untuk menguasai dan melindungi orang atau barang. (Kamal Muchtar, 1974:89)

Wali dalam perkawinan adalah merupakan „rukun” artinya harus ada dalam perkawinan. Tanpa adanya wali, perkawinan dianggap tiak sah, terutama perkawinan dari orangyang belum mukallaf. Adapun yang menjadi dasar hukumnya adalah hadist nabi di bawah ini:

(a) "Barang siapa diantara perempuan yang nikah dengan tidak diijinkan oleh walinya, maka perkawinannya batal" (Riwayat empat orang ahli Hadist, kecuali Nasaii)

(b) Janganlah menikahkan perempuan akan perempuan yg lain, dan jangan pula menikahkan seorang perempuan akan dirinya sendiri: (Riwayat Ibnu Majah dan Daruquthni).

\section{Orang-orang yang Boleh Menjadi Wali}

Karena tidak ada nash yang menerangkan urutan wali dengan jelas, maka dari itu para ahli berbeda pendapat dalam menetapkan urutan para wali sesuai dengan dasar-dasar yang mereka gunakan. Tetapi kebanyakan ulama berpendapat bahwa orang-orang yang berhak menjadi wali adalah:

1. Ayah kakek dan seterusnya ke atas dari garis laki-laki;

2. Saudara laki-laki kandung dan seayah;

3. Kemenakan laki-laki sekandung atau seayah;

4. Paman sekandung atau seayah;

5. Saudara sepupu laki-laki sekandung atau seayah;

6. Saudara sepupu laki-laki sekandung atau seayah;

7. Sultan (penguasa) sebagai wali hakim;

8. Wali yang diangkat oleh mempelai perempuan.

Di Idonesia yang dianut adalah tertib wali menurut madzhab Syafi'i. Adapun tertib wali menurut madzhab Syafi'i ialah:

1. Ayah;

2. Kakek dan seterusnya ke atas dar garis laki-laki;

3. Saudara laki-laki kandung;

4. Saudara laki-laki seayah;

5. Kemenakan laki-laki kandung;

6. Kemenakan laki-laki seayah;

7. Paman kandung;

8. Paman seayah;

9. Saudara sepupu laki-laki kandung;

10. Saudara sepupu laki-laki seayah;

11. Sultan atau hakim;

12. Orang yang ditunjuk oleh mempelai yang bersangkutan. 
Ad.4. Kewajiban membayar mahar bagi pihak laki-laki.

Mahar adalah suatu pemberian wajib dari suami kepada isterinya. Dengan demikian seorang wanita telah menjadi isterinya apabila akad nikah telah dilaksanakan, sehingga hak isteri atas mahar adalah sejak akad nikah selesai dilakukan.

Masalah mahar terdapat dalam Al-qur'an Surah an-Nisaa' ayat 20-21 yang menyebutkan:

"Apabila kamu ingin mengganti isterimu dengan isteri yang lain, sedang kamu telah memberikan kepada salah seorang diantara mereka mahar berapapun jumlahnya, amka janganlah kamu mengambil kembali sedikitpun juga mahar itu; apakah kamu akan mengambil kembali dengan jalan tuduhan dusta dan dengan menanggung dosa yang nyata? Bagaimana kamu akan mengambil kembali padahal antara kamu suami isteri telah bergaul (bercampur); dan isteriisteri itu telah mengambil janji yang kuat dari kamu?"

Ad.5. Harus ada pengucapan sighat "ijab dan kabul"

Sighat akad nikah ialah perkataanperkataan atau ucapan-ucapan yang diucapkan oleh calon suami dan calon isteri. Sighat akad-nikah terdiri dari „ijab” dan „kabul”.

"Ijab" ialah pernyataan dari pihak calon isteri, yang biasanya dilakukan oleh wali pihak calon isteri yang maksudnya bersedia dinikahkan dengan calon suaminya. "Kabul" ialah pernyataan atau jawaban pihak calon suami bahwa ia menerima kesediaan calon isterinya menjadi isterinya.

Supaya shighat akad-nikah ini sah harus memenuhi beberapa syarat tertentu, yaitu:

(1) Pada dasarnya akad nikah harus diucapkan secara lisan;

(2) Dilakukan dalam satu majelis;

(3) Antara ijab dan kabul tidak boleh diselingi kata-kata lain atau perbuatanperbuatan lain yang dapat dipandang mempunyai maksud mengalihkan akad yang sedang dilangsungkan;

(4) Ijab kabul tidak boleh digantungkan pada suatu syarat, disandarkan pada waktu yang akan datang, atau dibatasi dengan jangka waktu tertentu;

(5) Masing-masing pihak harus mendengar dan memahami perkataan atau isyaratisyarat yang diucapkan atau dilakukan oleh masing-masing di waktu aqad nikah.

Pasal 2 ayat 2 Undang-undang Perkawinan menentukan bahwa tiap-tiap perkawinan dicatat menurut peraturan perundang-undangan yang berlaku. Dengan tidak menjeaskan tentang maksud diadakannya pencatatan itu, dalam Penjelasan Umum hanya dikatakan bahwa tiap-tiap perkawinan adalah sama halnya dengan pencatatan peristiwa penting dalam kehidupan seseorang, misalnya kelahiran, kematian, yang dinyatakan dalam surat-surat 
keterangan, surat akta resmi yang juga dimuat dalam daftar pencatatan.

Kiranya dapatlah dikatakan bahwa pencatatan perkawinan itu bertujuan untuk menjadikan peristiwa perkawinan itu menjadi jelas, baik bagi yang bersangkutan maupun bagi orang lain dan masyarakat, karena dapat dilihat dalam suatu surat yang bersifat resmi dan termuat pula dalam suatu daftar yang khusus disediakan untuk itu, sehingga sewaktu-waktu dapat dipergunakan pada saat diperlukan, terutama sebagai alat bukti tertulis yang otenyik. Dengan adanya surat bukti itu dapatlah dibenarkan atau dicegah suatu perbuatan yang lain.

Perbuatan pencaatan ini tidaklah menentukan „sah”-nya suatu perkawinan, tetapi menyatakan bahwa peristiwa perkawinan itu memang ada dan terjadi, jadi semata-ata bersifat administratif. Sedangkan soal ,sah”nya perkawinan, di dalam UU Perkawinan dengan tegas menyatakan bahwa, „perkawinan adalah sah, apabila dilakukan menurut hukum agamanya dan kepercayaannya itu”.

Pernikahan "siri" sering diartikan oleh masyarakat umum dengan; Pertama; pernikahan tanpa wali. Pernikahan semacam ini dilakukan secara rahasia (siri) dikarenakan pihak wali perempuan tidak setuju; atau karena menganggap absah pernikahan tanpa wali; atau hanya karena ingin memuaskan nafsu syahwat belaka tanpa mengindahkan lagi ketentuan-ketentuan syariat; Kedua, pernikahan yang sah secara agama namun tidak dicatatkan dalam lembaga pencatatan negara. Banyak faktor yang menyebabkan seseorang tidak mencatatkan pernikahannya di lembaga pencatatan sipil negara. Ada yang karena faktor biaya, alias tidak mampu membayar administrasi pencatatan; ada pula yang disebabkan karena takut ketahuan melanggar aturan yang melarang pegawai negeri nikah lebih dari satu; dan lain sebagainya; Ketiga, pernikahan yang dirahasiakan karena pertimbangan-pertimbangan tertentu; misalnya karena takut mendapatkan stigma negatif dari masyarakat yang terlanjur menganggap tabu pernikahan siri; atau karena pertimbangan-pertimbangan rumit yang memaksa seseorang untuk merahasiakan pernikahannya.

Adapun hukum syariat atas ketiga fakta tersebut adalah sebagai berikut.

a. Hukum Pernikahan Tanpa Wali

Adapun mengenai fakta pertama, yakni pernikahan tanpa wali; sesungguhnya Islam telah melarang seorang wanita menikah tanpa wali. Ketentuan semacam ini didasarkan pada sebuah hadits yang dituturkan dari sahabat Abu Musa ra; bahwasanya Rasulullah saw bersabda;

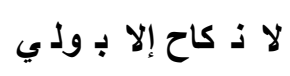

"Tidak sah suatu pernikahan tanpa seorang wali." [HR yang lima kecuali Imam An Nasaaiy, lihat, Imam Asy 
Syaukani, Nailul Authar VI: 230 hadits ke 2648].

Berdasarkan dalalah al-iqtidla', kata "laa" pada hadits menunjukkan pengertian 'tidak sah', bukan sekedar 'tidak sempurna' sebagaimana pendapat sebagian ahli fikih. Makna semacam ini dipertegas dan diperkuat oleh haditsyang diriwayatkan oleh Aisyah ra, bahwasanya Rasulullah saw pernah bersabda:

ذ كحت بـ غ ير إذن ول بها ف ذ ذكاحها أب ما امرأة

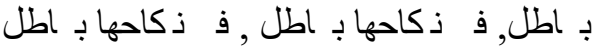

"Wanita mana pun yang menikah tanpa mendapat izin walinya, maka pernikahannya batil; pernikahannya batil; pernikahannya batil". [HR yang lima kecuali Imam An Nasaaiy. Lihat, Imam Asy Syaukaniy, Nailul Authar VI: 230 hadits ke 2649].

Abu Hurayrah ra juga meriwayatkan sebuah hadits, bahwasanya Rasulullah saw bersabda:

$$
\begin{aligned}
& \text { لا ت زوج الـ مرأة الـرأة لا ت زوج ذـ ف سها ف إن }
\end{aligned}
$$

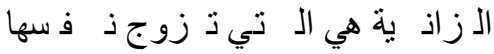

"Seorang wanita tidak boleh menikahkan wanita lainnya. Seorang wanita juga tidak berhak menikahkan dirinya sendiri. Sebab, sesungguhnya wanita pezina itu adalah (seorang wanita)yang menikahkan dirinya sendiri". (HR Ibn Majah dan Ad Daruquthniy. Lihat, Imam Asy Syaukaniy, Nailul Authar VI: 231 hadits ke 2649)

Berdasarkan hadits-hadits di atas dapatlah disimpulkan bahwa pernikahan tanpa wali adalah pernikahan batil. Pelakunya telah melakukan maksiyat kepada Allah swt, dan berhak mendapatkan sanksi di dunia. Hanya saja, syariat belum menetapkan bentuk dan kadar sanksi bagi orangorangyang terlibat dalam pernikahan tanpa wali. Oleh karena itu, kasus pernikahan tanpa wali dimasukkan ke dalam bab ta'zir, dan keputusan mengenai bentuk dan kadar sanksinya diserahkan sepenuhnya kepada seorang qadliy (hakim). Seorang hakim boleh menetapkan sanksi penjara, pengasingan, danlain sebagainya kepada pelaku pernikahan tanpa wali.

\section{b. Nikah Tanpa Dicatatkan Pada Lembaga}

\section{Pencatatan Sipil}

Adapun fakta pernikahan siri kedua, yakni pernikahan yang sah menurut ketentuan syariat namun tidak dicatatkan pada lembaga pencatatan sipil; sesungguhnya ada dua hukum yang harus dikaji secara berbeda; yakni (1) hukum pernikahannya; dan (2) hukum tidak mencatatkan pernikahan di lembaga pencatatan negara

Dari aspek pernikahannya, nikah siri tetap sah menurut ketentuan syariat, dan pelakunya tidak boleh dianggap melakukan tindak kemaksiyatan, sehingga berhak dijatuhi sanksi hukum. Pasalnya, suatu perbuatan baru dianggap kemaksiyatan dan berhak dijatuhi sanksi di dunia dan di akherat, ketika perbuatan tersebut terkategori "mengerjakanyang haram" dan "meninggalkan yang wajib". Seseorang baru absah dinyatakan melakukan kemaksiyatan ketika ia telah mengerjakan perbuatan yang haram, atau meninggalkan kewajiban yang telah ditetapkan oleh syariat. 
Begitu pula orang yang meninggalkan atau mengerjakan perbuatan-perbuatan yang berhukum sunnah, mubah, dan makruh, maka orang tersebut tidak boleh dinyatakan telah melakukan kemaksiyatan; sehingga berhak mendapatkan sanksi di dunia maupun di akherat. Untuk itu, seorang qadliy tidak boleh menjatuhkan sanksi kepada orangorangyang meninggalkan perbuatan sunnah, dan mubah; atau mengerjakan perbuatan mubah atau makruh.

Seseorang baru berhak dijatuhi sanksi hukum di dunia ketika orang tersebut; pertama, meninggalkan kewajiban, seperti meninggalkan sholat, jihad, danlain sebagainya; kedua, mengerjakan tindak haram, seperti minum khamer dan mencaci Rasul saw, dan lain sebagainya; ketiga, melanggar aturan-aturan administrasi negara, seperti melanggar peraturan lalu lintas, perijinan mendirikan bangunan, dan aturanaturanlain yang telah ditetapkan oleh negara.

Berdasarkan keterangan dapat disimpulkan; pernikahan yang tidak dicatatkan di lembaga pencatatan negara tidak boleh dianggap sebagai tindakan kriminal sehingga pelakunya berhak mendapatkan dosa dan sanksi di dunia. Pasalnya, pernikahanyang ia lakukan telah memenuhi rukun-rukun pernikahan yang digariskan oleh Allah swt. Adapun rukunrukun pernikahan adalah sebagai berikut; (1) wali, (2) dua orang saksi, dan (3) ijab qabul. Jika tiga hal ini telah dipenuhi, maka pernikahan seseorang dianggap sah secara syariat walaupun tidak dicatatkan dalam pencatatan sipil.

Adapun berkaitan hukum tidak mencatatkan pernikahan di lembaga pencatatan negara, maka kasus ini dapat dirinci sebagai berikut:

Pertama, pada dasarnya, fungsi pencatatan pernikahan pada lembaga pencatatan sipil adalah agar seseorang memiliki alat bukti (bayyinah) untuk membuktikan bahwa dirinya benar-benar telah melakukan pernikahan dengan oranglain. Sebab, salah bukti yang dianggap absah sebagai bukti syar'iy (bayyinah syar'iyyah) adalah dokumen resmi yang dikeluarkan oleh negara. Ketika pernikahan dicatatkan pada lembaga pencatatan sipil, tentunya seseorang telah memiliki sebuah dokumen resmiyang bisa ia dijadikan sebagai alat bukti (bayyinah) di hadapan majelis peradilan, ketika ada sengketa yang berkaitan dengan pernikahan, maupun sengketa yang lahir akibat pernikahan, seperti waris, hak asuh anak, perceraian, nafkah, dan lain sebagainya. Hanya saja, dokumen resmi yang dikeluarkan oleh negara, bukanlah satusatunya alat bukti syar'iy. Kesaksian dari saksi-saksi pernikahan atau orang-orang yang menyaksikan pernikahan, juga absah dan harus diakui oleh negara sebagai alat bukti syar'iy.

Negara tidak boleh menetapkan bahwa satu-satunya alat bukti untuk membuktikan 
keabsahan pernikahan seseorang adalah dokumen tertulis. Pasalnya, syariat telah menetapkan keabsahan alat buktilain selain dokumen tertulis, seperti kesaksian saksi, sumpah, pengakuan (iqrar), dan lain sebagainya. Berdasarkan penjelasan ini dapatlah disimpulkan bahwa, orang yang menikah siri tetap memiliki hubungan pewarisan yang sah, dan hubungan-hubungan lain yang lahir dari pernikahan. Selain itu, kesaksian dari saksi-saksi yang menghadiri pernikahan siri tersebut sah dan harus diakui sebagai alat bukti syar'iy. Negara tidak boleh menolak kesaksian mereka hanya karena pernikahan tersebut tidak dicatatkan pada lembaga pencatatan sipil; atau tidak mengakui hubungan pewarisan, nasab, dan hubungan-hubunganlain yang lahir dari pernikahan siri tersebut.

Kedua, pada era keemasan Islam, di mana sistem pencatatan telah berkembang dengan pesat dan maju, tidak pernah kita jumpai satupun pemerintahan Islam yang mempidanakan orang-orang yang melakukan pernikahan yang tidak dicatatkan pada lembaga pencatatan resmi negara. Lebih dari itu, kebanyakan masyarakat pada saat itu, melakukan pernikahan tanpa dicatat di lembaga pencatatan sipil. Tidak bisa dinyatakan bahwa pada saat itu lembaga pencatatan belum berkembang, dan keadaan masyarakat saat itu belumnya sekompleks keadaan masyarakat sekarang. Pasalnya, para penguasa dan ulama-ulama kaum Muslim saat itu memahami bahwa hukum asal pencatatan pernikahan bukanlah wajib, akan tetapi mubah. Mereka juga memahami bahwa pembuktian syar'iy bukan hanya dokumen tertulis.

Rasulullah saw sendiri melakukan pernikahan, namun kita tidak pernah menemukan riwayat bahwa melakukan pencatatan atas pernikahan beliau, atau beliau mewajibkan para shahabat untuk mencatatkan pernikahan mereka; walaupun perintah untuk menulis (mencatat) beberapa muamalah telah disebutkan di dalam alQuran, misalnya firman Allah swt;

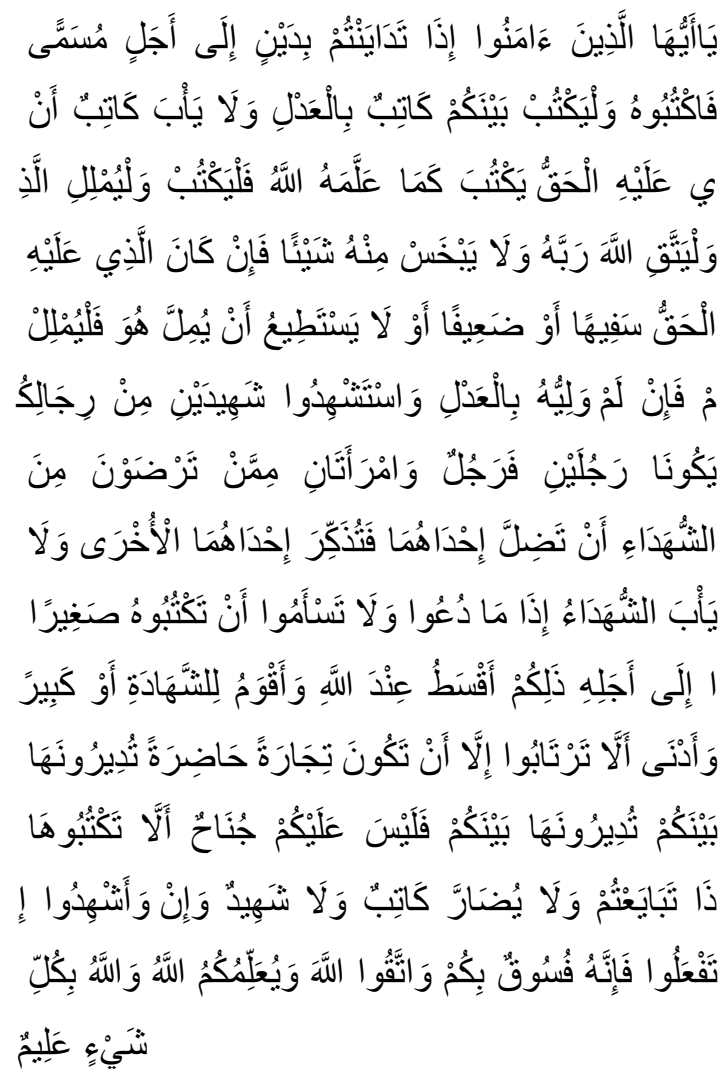

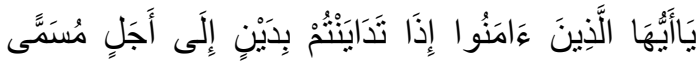

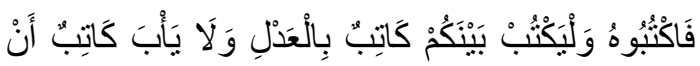

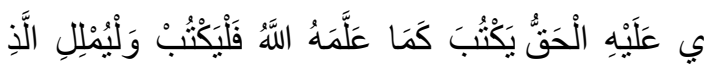

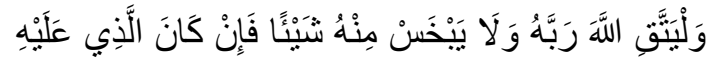

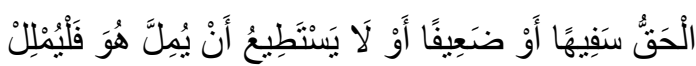

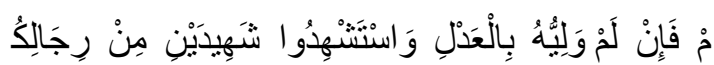

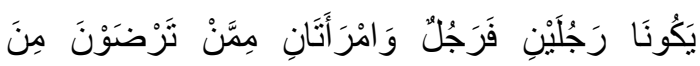

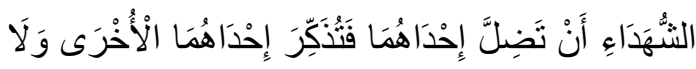

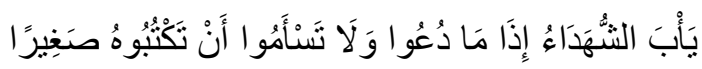

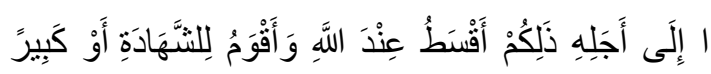

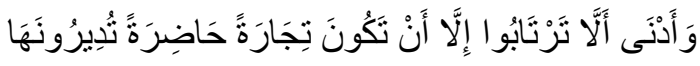

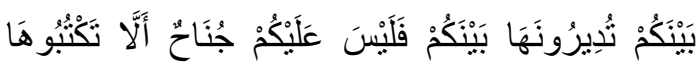

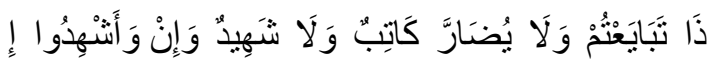

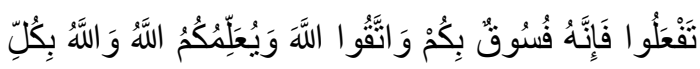

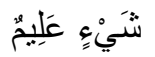

"Hai orang-orang yang beriman, apabila kamu bermu amalah tidak secara tunai untuk waktu yang ditentukan, hendaklah kamu menuliskannya. Dan hendaklah seorang penulis di antara kamu menuliskannya dengan benar. Dan janganlah penulis 
enggan menuliskannya sebagaimana Allah telah mengajarkannya, maka hendaklah ia menulis, dan hendaklah orang yang berhutang itu mengimlakkan (apa yang akan ditulis itu), dan hendaklah ia bertakwa kepada Allah Tuhannya, dan janganlah ia mengurangi sedikitpun daripada hutangnya. Jika yang berhutang itu orang yang lemah akalnya atau lemah (keadaannya) atau dia sendiri tidak mampu mengimlakkan, maka hendaklah walinya mengimlakkan dengan jujur. Dan persaksikanlah dengan dua orang saksi dari orangorang lelaki diantaramu). Jika tak ada dua orang lelaki, maka (boleh) seorang lelaki dan dua orang perempuan dari saksi-saksi yang kamu ridhai, supaya jika seorang lupa maka seorang lagi mengingatkannya. Janganlah saksi-saksi itu enggan (memberi keterangan) apabila mereka dipanggil; dan janganlah kamu jemu menulis hutang itu, baik kecil maupun besar sampai batas waktu membayarnya. Yang demikian itu, lebih adil di sisi Allah dan lebih dapat menguatkan persaksian dan lebih dekat kepada tidak (menimbulkan) keraguanmu, (Tulislah mu`amalahmu itu), kecuali jika mu'amalah itu perdagangan tunai yang kamu jalankan di antara kamu, maka tak ada dosa bagi kamu, (jika) kamu tidak menulisnya. Dan persaksikanlah apabila kamu berjual beli; dan janganlah penulis dan saksi saling sulit-menyulitkan. Jika kamu lakukan (yang demikian), maka sesungguhnya hal itu adalah suatu kefasikan pada dirimu. Dan bertakwalah kepada Allah; Allah mengajarmu; dan Allah Maha Mengetahui segala sesuatu”. [QS AL Baqarah (2):

Ketiga, dalam khazanah peradilan Islam, memang benar, negara berhak menjatuhkan sanksi mukhalafat kepada orang yang melakukan tindakan mukhalafat. Pasalnya, negara (dalam hal ini seorang
Khalifah dan orang yang diangkatnya) mempunyai hak untuk menetapkan aturanaturan tertentu untuk mengatur urusan-urusan rakyat yang belum ditetapkan ketentuan dan tata cara pengaturannya oleh syariat; seperti urusan lalu lintas, pembangunan rumah, eksplorasi, dan lain sebagainya. Khalifah memiliki hak dan berwenang mengatur urusan-urusan semacam ini berdasarkan ijtihadnya. Aturan yang ditetapkan oleh khalifah atau qadliy dalam perkara-perkara semacam ini wajib ditaati dan dilaksanakan oleh rakyat. Siapa saja yang melanggar ketetapan khalifah dalam urusan-urusan tersebut, maka ia telah terjatuh dalam tindakan mukhalafat dan berhak mendapatkan sanksi mukhalafat. Misalnya, seorang khalifah berhak menetapkan jarak halaman rumah dan jalan-jalan umum, dan melarang masyarakat untuk membangun atau menanam di sampingnya pada jarak sekian meter. Jika seseorang melanggar ketentuan tersebut, khalifah boleh memberi sanksi kepadanya dengan denda, cambuk, penjara, dan lain sebagainya.

Khalifah juga memiliki kewenangan untuk menetapkan takaran, timbangan, serta ukuran-ukuran khusus untuk pengaturan urusan jual beli dan perdagangan. Ia berhak untuk menjatuhkan sanksi bagi orang yang melanggar perintahnya dalam hal tersebut. Khalifah juga memiliki kewenangan untuk menetapkan aturan-aturan tertentu untuk kafe-kafe, hotel-hotel, tempat penyewaan 
permainan, dan tempat-tempat umum lainnya; dan ia berhak memberi sanksi bagi orang yang melanggar aturan-aturan tersebut.

Demikian juga dalam hal pengaturan urusan pernikahan. Khalifah boleh saja menetapkan aturan-aturan administrasi tertentu untuk mengatur urusan pernikahan; misalnya, aturan yang mengharuskan orangorang yang menikah untuk mencatatkan pernikahannya di lembaga pencatatan resmi negara, dan lain sebagainya. Aturan semacam ini wajib ditaati dan dilaksanakan oleh rakyat. Untuk itu, negara berhak memberikan sanksi bagi orang yang tidak mencatatkan pernikahannya ke lembaga pencatatan negara. Pasalnya, orang yang tidak mencatatkan pernikahannya di lembaga pencatatan negara -- padahal negara telah menetapkan aturan tersebut - telah terjatuh pada tindakan mukhalafat. Bentuk dan kadar sanksi mukhalafat diserahkan sepenuhnya kepada khalifah dan orang yang diberinya kewenangan.

Yang menjadi catatan di sini adalah, pihak yang secara syar'iy absah menjatuhkan sanksi mukhalafat hanyalah seorang khalifah yang dibai'at oleh kaum Muslim, dan orang yang ditunjuk oleh khalifah. Selain khalifah, atau orang-orang yang ditunjuknya, tidak memiliki hak dan kewenangan untuk menjatuhkan sanksi mukhalafat. Atas dasar itu, kepala negara yang tidak memiliki aqad bai'at dengan rakyat, maka kepala negara semacam ini tidak absah menjatuhkan sanksi mukhalafat kepada rakyatnya. Sebab, seseorang baru berhak ditaati dan dianggap sebagai kepala negara jika rakyat telah membai'atnya dengan bai' at in'iqad dan taat. Adapun orang yang menjadi kepala negara tanpa melalui proses bai'at dari rakyat (in'iqad dan taat), maka ia bukanlah penguasa yang sah, dan rakyat tidak memiliki kewajiban untuk mentaati dan mendengarkan perintahnya. Lebih-lebih lagi jika para penguasa itu adalah para penguasa yang menerapkan sistem kufur alas demokrasi dan sekulerisme, maka rakyat justru tidak diperkenankan memberikan ketaatan kepada mereka.

Keempat, jika pernikahan siri dilakukan karena faktor biaya; maka pada kasus semacam ini negara tidak boleh mempidanakan dan menjatuhkan sanksi mukhalafat kepada pelakunya. Pasalnya, orang tersebut tidak mencatatkan pernikahannya dikarenakan ketidakmampuannya; sedangkan syariat tidak membebani seseorang di luar batas kemampuannya. Oleh karena itu, Negara tidak boleh mempidanakan orang tersebut, bahkan wajib memberikan pelayanan pencatatan gratis kepada orang-orang yang tidak mampu mencatatkan pernikahannya di lembaga pencatatan Negara.

Kelima, pada dasarnya, Nabi saw telah mendorong umatnya untuk menyebarluaskan pernikahan dengan menyelenggarakan walimatul 'ursy. Anjuran untuk melakukan 
walimah, walaupun tidak sampai berhukum wajib akan tetapi nabi sangat menganjurkan (sunnah muakkadah). Nabi saw bersabda;

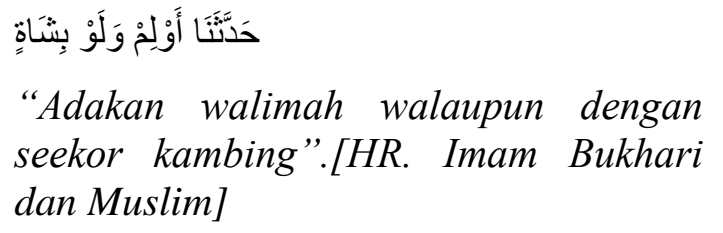

"Adakan walimah walaupun dengan seekor kambing”.[HR. Imam Bukhari dan Muslim]

Banyak hal-hal positif yang dapat diraih seseorang dari penyiaran pernikahan; di antaranya adalah ; (1) untuk mencegah munculnya fitnah di tengah-tengah masyarakat; (2) memudahkan masyarakat untuk memberikan kesaksiannya, jika kelak ada persoalan-persoalan yang menyangkut kedua mempelai; (3) memudahkan untuk mengidentifikasi apakah seseorang sudah menikah atau belum.

Hal semacam ini tentunya berbeda dengan pernikahan yang tidak disiarkan, atau dirahasiakan (siri). Selain akan menyebabkan munculnya fitnah; misalnya jika perempuan yang dinikahi siri hamil, maka akan muncul dugaan-dugaan negatif dari masyarakat terhadap perempuan tersebut; pernikahan siri juga akan menyulitkan pelakunya ketika dimintai persaksian mengenai pernikahannya. Jika ia tidak memiliki dokumen resmi, maka dalam semua kasus yang membutuhkan persaksian, ia harus menghadirkan saksi-saksi pernikahan sirinya; dan hal ini tentunya akan sangat menyulitkan dirinya. Atas dasar itu, anjuran untuk mencatatkan pernikahan di lembaga pencatatan negara menjadi relevan, demi mewujudkan kemudahan-kemudahan bagi suami isteri dan masyarakat serta untuk mencegah adanya fitnah.

\section{Kesimpulan}

UU No. 1 Tahun 1974, memiliki kelemahan, Pasal 2 tidak menegaskan pencatatan perkawinan sebagai syarat sahnya perkawinan. Hanya dikatakan bahwa sahnya suatu perkawinan apabila dilakukan menurut hukum agamanya masing-masing. Pencatatan perkawinan sama halnya dengan pencatatan peristiwa-peristiwa penting dalam kehidupan seseorang seperti kelahiran, kematian, dan lain-lain. Untuk menghindari terjadinya nikah siri yang mempunyai tujuan-tujuan tertentu maka pencatatan perkawinan dijadikan sebagai syarat sahnya suatu perkawinan. Pencatatan perkawinan juga bertujuan untuk memberikan kepastian dan perlindungan hukum bagi kaum wanita dan anak-anaknya.

\section{Daftar Pustaka}

Abdul Rahman Ghozali, (2003), Fiqh Munakahat, Prenada Media Group, Jakarta

Ahmad Azhar Basyir, (1977), Hukum Perkawinan Islam, UII Press, Yogyakarta.

K. Wantjik Saleh, (1976), Hukum Perkawinan Indonesia, Ghalia Indonesia, Jakarta. 
Kamal Muchtar, (1974), Asas-Asas Hukum Islam Tentang Perkawinan, Bulan Bintang, Jakarta

Mohd. Idris Ramulyo, (1996), Hukum Perkawinan Islam- Suatu Analisis dari UU No.1 Tahun 1974 dan Kompilasi Hukum Islam, Bumi Aksara, Jakarta

Nadimah Tanjung, TT, Islam dan Perkawinan, Bulan Bintang, Jakart.

Saidus Syahar, (1998), Asas-Asas Hukum Islam, Alimni, Bandung

Soemiyati, (1986), Hukum Perkawinan Islam dan Undang-Undang Perkawinan, Liberty, Yogyakarta 